\title{
ROAD TRANSPORT CORRIDORS TO ECOLOGICAL TRANSITION IN SPAIN
}

\author{
JOSÉ LUIS MIRALLES I GARCIA \\ Department of Urban Planning, Polytechnic University of Valencia, Spain
}

\begin{abstract}
Last December 2020, the European Commission welcomes the political agreement reached between the European Parliament and the Council on the Recovery and Resilience Facility (RRF) already approved. RRF will be structured around six pillars. Between them, the first pillar is 'green transition'. Green transition includes the goal of balanced $\mathrm{CO}_{2}$ emissions in 2050. Inside this framework, European transport system must to achieve climate neutrality by 2050 . This objective implies recovery transport system to sustainable modes. One of main ways to make the change is translate passengers and freight transport from road to railways that avoid greenhouse emissions if it uses electric energy with sustainable origins. To planning the change is important to now the mobility of passengers and freight by road. This article analyses the mobilities' situation in Spain by road represented such as network of main nodes and trams, passengers and freight, for medium and large distance in 2017.

Keywords: ecological transition, European corridors, mobility, Sustainable transport.
\end{abstract}

\section{INTRODUCTION}

\subsection{Previous discussion}

The consequences of urban transport in air pollution are well known for a long time. For example, European Commission was working about the urban environment from 1980s and sent a Communication to the Council and Parliament already in 1990. This communication has the title 'Green Paper on the Urban Environment' [1] and describe the environmental situation of European cities at the moment and identify the main environmental problems, air pollution produced by traffic between them. But before, some authors such as Colin Buchanan in 1963 [2] or Jane Jacobs in 1961 [3], showed the negative consequences of traffic for society. The urban environmental question has been analysed extensively. In Spain the analysis was updated in 2007 [4] by a report promoted by Ministry of Environment ('Ministerio del Medio Ambiente' in Spanish) and in 2012 [5] by a report promoted by Ministry of Agriculture, Food and Environment ('Ministerio de Agricultura, Alimentación y Medio Ambiente' in Spanish).

In consequence, there is a need to change the transport system of cities and territory to improve quality of live and avoid dependence of oil in Europe. This change presents many facets. On the one hand, there are some transport modes: road, maritime, air, railway, channels, etc. In second place, there are passenger and freight transport. In the third place, the efficiency and characteristics of transport are function of distances origin-destination. And finally, transport technology is changing continuously, and as a consequence, the boundary conditions to optimize the efficiency of the transport system also change continuously. In addition, if technology can change rapidly, to the contrary changes in territorial infrastructures to adapt them are very slow and often costly.

Progressively, the analysis of transport system has been changing towards an approach from the point of view of mobility. That is, an approach that consider the movement of passenger/freight from origin to destination by a travel which usually is doing by several transport modes. 
With this framework, explained in a synthetic way, it is easy to understand that there are many different ways to change the transport system towards more sustainable modes. That is, to generate a transport system, or a mobility system, with less/zero greenhouse gases emission and energy consumption from sustainable sources.

This article is focused about the potential change to translate passengers and freight from road to railways in Spain. In Spain, there are some railway network:

a) High speed rail (HSR); electric energy AC $25 \mathrm{kV}$ and $50 \mathrm{~Hz}$; width international UIC $(1,435 \mathrm{~mm})$; maximal speed $\sim 300 \mathrm{~km} / \mathrm{h}$.

b) Conventional train (CT); electric energy CC $3 \mathrm{kV}$; width Iberic IB (1,668 mm); maximal speed $\sim 200 \mathrm{~km} / \mathrm{h}$.

c) Regional trains; width $1 \mathrm{~m}$; only in some urban or metropolitan areas.

From of point of view of passenger transport, HSR is more competitive front air transport in distances between 200 and $500 \mathrm{~km}$ approximately. However, CT is progressively improving its possibilities increasing maximal speed and capacity to move by both widths, UIC and IB, in the same travel. In this situation, it is possible to consider approximately three type of distances for passengers:

a) $\quad$-200 km: close distances; in general, urban or metropolitan areas have borders inside this size.

b) $200-500 \mathrm{~km}$ : long distances; in general, approximately, urban or metropolitan areas in Spain have these distances between them

c) More than $500 \mathrm{~km}$ : in general, in this case, air transport is more competitive than railway.

In any case, usually passenger by train need use others transport to the 'last mile'. That is, railway travel is station-station and passenger need in addition move from origin to initial station and from final station to destination. On the contrary, road mode allows 'door-to-door' travel or a trip directly from origin to destination. Of course, car travels in urban or metropolitan areas have other kind of problems such as congestion.

For freight transport the situation is different. Railway can be an alternative to road mode but always will be necessary to do the 'last mile' by road. In addition, with some exception, air mode is not alternative to road mode that can move big quantities of merchandises. In this situation, distances less than $200 \mathrm{~km}$ probably always is more competitive the road move. For longer distances it is possible that the railway can compete with the road but, in this case, other variables can be very determinants, for example, the efficiency of loading-unloading in the 'last mile' from origin or to destination.

This article is focused on the potential to translate passengers and freight from road to railway in Spain according to the number of passengers and quantity of freight that exist in the different transport corridors.

\subsection{Evolution of modal split in Europe and Spain}

To understand how it is possible to produce an ecological transition of transport system and mobility, it is convenient to know last trends on modal split in Europe and Spain. In Table 1, the evolution of modal split for passenger transport from 1995 to 2016 is shown. In Fig.1, the evolution of passenger-kilometre for each transport mode is shown. The proportion of passenger cars decreases but very little and maintain a proportion between $71 \%$ and $73 \%$. The 
most ecological transport modes, railway and tram \& metro, practically do not change their proportion or their importance as a means of transport. On the contrary, the only mode that increase it importance is air transport, from $6.5 \%$ to $10.5 \%$, that also is the mode that produces more greenhouse gases per passenger. Figure 1 shows that the quantity of passengerkilometre increases for cars, air and tram \& metro modes. So, in fact, the quantity of trips by the most polluting modes increases. Obviously, in these conditions, there are many potential

Table 1: Evolution of modal split for passenger transport in EU. (Source: European Commission [6])

\begin{tabular}{|c|c|c|c|c|c|c|c|}
\hline \multicolumn{8}{|c|}{ MODAL SPLIT (\%) } \\
\hline & $\begin{array}{c}\text { PASSENGER } \\
\text { CARS }\end{array}$ & $\mathrm{P} 2 \mathrm{~W}$ & $\begin{array}{l}\text { BUS \& } \\
\text { COACH }\end{array}$ & RAILWAY & $\begin{array}{l}\text { TRAM \& } \\
\text { METRO }\end{array}$ & AIR & SEA \\
\hline 1995 & 73.2 & 2.1 & 9.6 & 6.6 & 1.4 & 6.5 & 0.6 \\
\hline 2000 & 72.9 & 1.8 & 9.3 & 6.3 & 1.4 & 7.8 & 0.5 \\
\hline 2005 & 72.7 & 1.9 & 8.8 & 6.1 & 1.4 & 8.5 & 0.5 \\
\hline 2006 & 72.5 & 1.9 & 8.7 & 6.2 & 1.4 & 8.8 & 0.4 \\
\hline 2007 & 72.2 & 1.8 & 8.8 & 6.2 & 1.4 & 9.0 & 0.4 \\
\hline 2008 & 72.0 & 1.9 & 8.9 & 6.5 & 1.5 & 8.8 & 0.5 \\
\hline 2009 & 73.1 & 1.9 & 8.6 & 6.3 & 1.5 & 8.2 & 0.4 \\
\hline 2010 & 72.8 & 1.9 & 8.6 & 6.4 & 1.5 & 8.4 & 0.4 \\
\hline 2011 & 72.0 & 1.9 & 8.6 & 6.5 & 1.5 & 9.0 & 0.4 \\
\hline 2012 & 71.7 & 20 & 8.7 & 6.7 & 1.6 & 9.1 & 0.3 \\
\hline 2013 & 71.7 & 1.9 & 8.6 & 6.7 & 1.6 & 9.1 & 0.3 \\
\hline 2014 & 71.6 & 1.9 & 8.4 & 6.7 & 1.6 & 9.5 & 0.3 \\
\hline 2015 & 71.5 & 1.9 & 8.3 & 6.7 & 1.5 & 9.7 & 0.3 \\
\hline 2016 & 71.0 & 1.9 & 8.1 & 6.6 & 1.6 & 10.5 & 0.4 \\
\hline
\end{tabular}

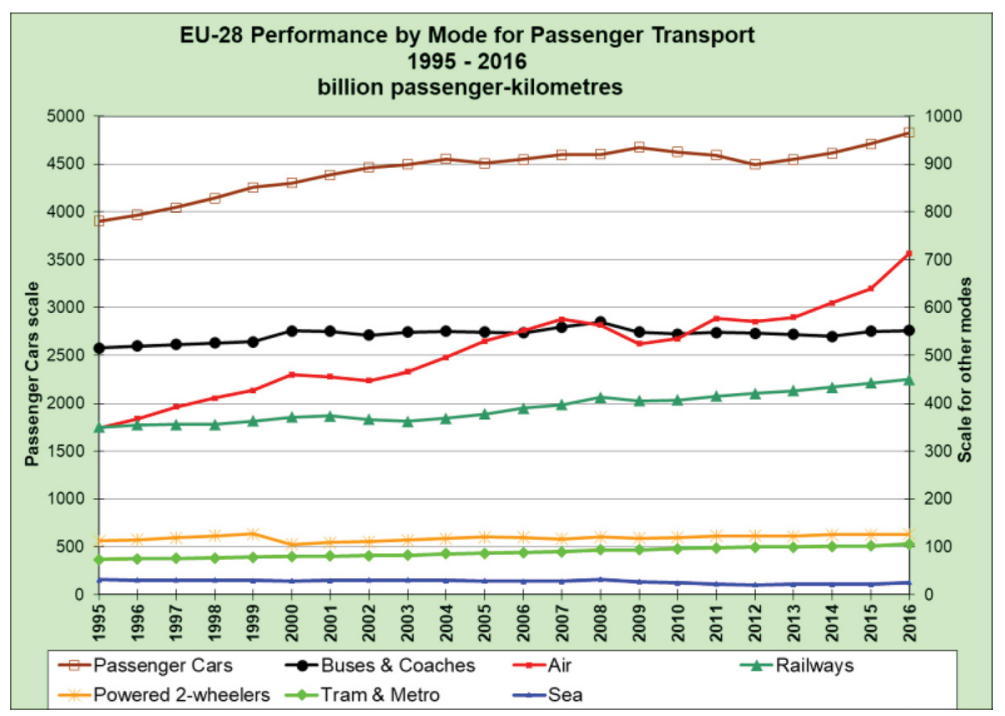

Figure 1: EU performance by mode for passenger transport. (Source: European Commission [6]) 
possibilities to reduce greenhouse gases emissions moving passengers from not ecological modes to ecological modes, that is, from cars, bus \& coach and air transport to railway and tram \& metro.

In addition, of course, changes in technology also allow to achieve the goal of greenhouse gases reduction. So, electric or hydrogen cars and buses allow eliminate greenhouse gases emissions. Probably the final scenario will be a combination of both possibilities.

In Table 2, the evolution of modal split for freight transport from 1995 to 2016 is shown. The proportion of freight transport by road increases from $45.3 \%$ in 1995 to $49.3 \%$ in 2016 . The most ecological transport mode, railway, decreases from $13.6 \%$ to $11.2 \%$. The others one transport modes maintain its proportions. In addition, note you that inland Europe sea transport is really very low. So most of the sea transport is international transport out of Europe and the proportion of road transport inland Europe is much higher, about $72.8 \%$ in 2016.

Figure 2 shows the evolution of tonne-kilometre transported by each transport mode. The quantity of tonne-kilometre transported by rail, inland waterway, oil pipeline and air is practically constant. Only transport by road or sea increasing.

In consequence, in these conditions also there are many potential possibilities to reduce greenhouse gases emissions moving freight from not ecological modes, specially road, to ecological modes, specially railway. This change of freight transport mode is possible for a long distance because for a short distance door-to-door, freight transport by truck is more competitive.

Table 3 and 4 shows the particular evolution of modal split in Spain for passenger and freight transport. The transport distribution between road and railway transport in Spain is more unbalanced than Europe. Thus, for passengers $87.33 \%$ of transport in 2015 was by road and only $6.38 \%$ was by railway. For freight transport, there was $82.38 \%$ by road or truck and only $3.52 \%$ by railway. Therefore, the situation in Spain is more radical than Europe and, in consequence, there is more potential possibilities to translate passenger and freight transport from road to railway.

On the other hand, the situation of railway network is complicated in Spain as discussed in section 1.1. Spain decided to develop a railway network for HSR in 1990s with international width which allows connect directly with European railway network. The process to develop this new railway network progress little by little with different territorial impacts

Table 2: Evolution of modal split for freight transport in EU. (Source: European Commission [6])

\begin{tabular}{|c|c|c|c|c|c|c|}
\hline \multicolumn{7}{|c|}{ MODAL SPLIT (\%) } \\
\hline & ROAD & RAIL & $\begin{array}{c}\text { INLAND } \\
\text { WATERWAYS }\end{array}$ & PIPELINES & SEA & AIR \\
\hline 1995 & 45.3 & 13.6 & 4.3 & 4.0 & 32.7 & 0.1 \\
\hline 2000 & 46.5 & 12.5 & 4.1 & 3.9 & 32.9 & 0.1 \\
\hline 2005 & 48.6 & 11.5 & 3.8 & 3.8 & 32.2 & 0.1 \\
\hline 2010 & 49.4 & 11.4 & 4.5 & 3.5 & 31.2 & 0.1 \\
\hline 2011 & 48.7 & 12.1 & 4.1 & 3.4 & 31.7 & 0.1 \\
\hline 2012 & 48.5 & 12.0 & 4.4 & 3.4 & 31.7 & 0.1 \\
\hline 2013 & 48.7 & 11.8 & 4.4 & 3.3 & 31.7 & 0.1 \\
\hline 2014 & 48.2 & 11.8 & 4.3 & 3.2 & 32.4 & 0.1 \\
\hline 2015 & 48.9 & 11.9 & 4.2 & 3.3 & 31.7 & 0.1 \\
\hline 2016 & 49.3 & 11.2 & 4.0 & 3.1 & 32.3 & 0.1 \\
\hline
\end{tabular}




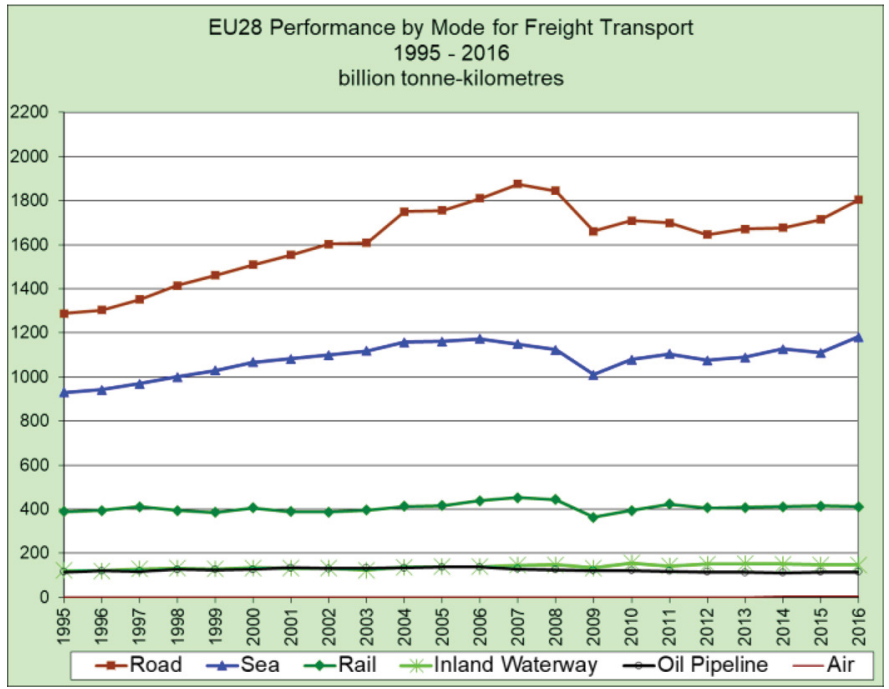

Figure 2: EU performance by mode for freight transport. (Source: European Commission [6])

Table 3: Evolution of modal split for passenger transport in Spain. (Source: Ministerio de Fomento [7])

\begin{tabular}{|r|r|r|r|r|r|r|} 
Modal & 2011 & 2012 & 2013 & 2014 & 2015 (P) & $\begin{array}{r}\text { Modal split } \\
2015\end{array}$ \\
\hline Road & 391.711 & 377.544 & 372.313 & 350.393 & 366.092 & $87,33 \%$ \\
\hline Railways & 23.313 & 23.016 & 24.323 & 25.663 & 26.747 & $6,38 \%$ \\
\hline Air & 30.410 & 26.678 & 23.537 & 23.895 & 25.392 & $6,06 \%$ \\
\hline Sea & 1.444 & 1.442 & 1.578 & 903 & 965 & $0,23 \%$ \\
\hline Total & 446.878 & 428.680 & 421.751 & 400.854 & 419.196 & $100,00 \%$ \\
\hline
\end{tabular}

Table 4: Evolution of modal split for freight transport in Spain. (Source: Ministerio de Fomento [7])

\begin{tabular}{|r|r|r|r|r|r|r|} 
Modal & 2011 & 2012 & 2013 & 2014 & $2015(\mathrm{P})$ & Modal split \\
transport & & & & & & \\
\hline Road & 264.806 & 241.973 & 237.455 & 243.915 & 254.875 & $82,38 \%$ \\
\hline Railways & 9.588 & 9.393 & 9.367 & 10.303 & 10.884 & $3,52 \%$ \\
\hline Sea & 41.680 & 40.365 & 39.367 & 40.449 & 43.580 & $14,09 \%$ \\
\hline Air & 77 & 67 & 62 & 68 & 64 & $0,02 \%$ \\
\hline Total & 316.151 & 291.798 & 286.251 & 294.735 & 309.403 & $100,00 \%$ \\
\hline
\end{tabular}


[8-12]. In fact, today in Spain there are several railway services: high speed rail (width UIC), regional by conventional train (width IB) and short distance (width IB). At the moment, the most efficient service to long distances in Spain is HSR if it exists. But we must remember that HSR infrastructure is not prepared to freight trains because HSR trains are swift and relatively light. They need a perfectly aligned infrastructure. On the contrary, freight trains are heavy and slow. They deform the alignment of the rails. In consequence, in general, the high-speed network is not suitable for freight transport. So, in Spain, freight transport uses conventional network (width IB). With exceptions (Catalonia-French), this network does not connect directly with European railway network.

On the other hand, Spain publishes about traffic on the national road network [13]. Data map shows the 'Intensidad Media Diaria (IMD)' (average daily intensity of traffic) in points with gauging station. Data includes total intensity and percentage of P2W, light and heavy vehicles, that is, motorbike or similar, private car or similar and trucks. Therefore, this data can be uses to calculate passenger and freight transport by road. Usually, traffic increases when we approach urban centres or centres of urban areas. In the case of close urban areas, the hinterland of both areas overlapping and both can be considered as a one functional area. This is the case of the cities Alacant-Elx, Málaga-Granada or Gasteiz-Bilbao-Donostia. With this hypothesis, it is possible to obtain the average daily intensity of private cars and trucks between urban areas located a long distance each other.

\subsection{Next Generation EU}

The Next Generation EU is the temporary instrument designed to boost the recovery, will be the largest stimulus package ever financed through the EU budget [14]. The Recovery and Resilience Facility is the centrepiece of Next Generation EU. According to European Commission: 'The aim is to mitigate the economic and social impact of the coronavirus pandemic and make European economies and societies more sustainable, resilient and better prepared for the challenges and opportunities of the green and digital transitions'. On 18 February 2021, Official Journal of the European Union published the REGULATION (EU) 2021/241 OF THE EUROPEAN PARLIAMENT AND OF THE COUNCIL of 12 February 2021 establishing the Recovery and Resilience Facility. This regulation stablishes in art. 3 the 6 pillars of European policy to apply Recovery and Resilience Facility (RRF). Inside the first pillar, green transition, there is the European policy to reach EU climate neutrality by 2050 . Consequently, move passengers and freight transport from road by vehicles with greenhouse gases emissions, to public transport as railway, especially electric with sustainable energy sources, is a direct way to achieve the green deal objectives.

\section{OBJECTIVES}

This article shows the results of a part of a study carried out for a group of municipalities in the surroundings of Valencia (Spain) for the development of a proposal for an arterial railway network in the metropolitan area of Valencia.

The objectives of this part of a study are to analyse the potential that exist to move passengers and freight from road modes to railways modes for long distance with especial attention about the situation of metropolitan area of València. Traffic for short distance, like urban or metropolitan traffic, is out of objectives of this study because it has especial characteristics. 


\section{MATERIAL AND METHODS}

\subsection{Data set}

Ministry of Transport, Mobility and Urban Agenda ('Ministerio de Transporte, Movilidad y Agenda Urbana' in Spanish) publish a traffic map for each year. At the time the study was done, the last traffic map published was from 2017. Data for 2018 are now available and its are similar to 2017. Note you that these data are before COVID period that start in Spain about January 2020. As discussed in section 1.2, data map shows the average daily intensity of traffic (IMD in Spanish) in points with gauging station on the national road network. In addition, includes percentage of light (cars and motorbike) and heavy (trucks) vehicles.

\subsection{Methods}

Based on traffic map, it is possible build the corridors road network. That is, the main movements of passengers and freight between the main nodes. To build the network, first the main nodes have been identified. These nodes are connected between them by road trams. There are three type of nodes: urban/metropolitan centres, road junctions and international connections. On the other hand, some important cities are very close between them. In these cases, we accept that the group of cities are an only functional area. That are the cases of AlacantElx, Málaga-Granada and Gasteiz-Bilbao-Donostia.

Traffic intensity increases when we approaching to urban/metropolitan nodes. Therefore, we can adopt the criteria that traffic flux between nodes will be the minimal IMD in each road tram to both passengers and freight transport. By this way we can obtain the IMD for each tram between nodes as number of light and heavy vehicles.

In addition, almost all light vehicles are cars with passengers. Then, let us consider the approximation that all light vehicles are cars with passengers. And we apply the same approximation to freight transport: all heavy vehicles are cargo trucks.

In the next phase, we estimate the number of passengers and the amount of cargo transported.

To estimate the number of passengers by tram we need to know the average number of passengers by car. El 'Observatorio del Transporte y la Logística en España' ('Observatory of Transport and Logistics in Spain' in English) publishes annual reports about the situation of transport in Spain. In the methodological annex of 2019 [15] establish that the occupancy coefficient of cars in inter-cities travels is 1.68 passengers/car. With this coefficient and the daily average intensity, it is possible to estimate the number of passengers by tram and year.

To estimate the number of tonnes transported by tram also it is necessary to know the average cargo by truck. The 'Observatorio del Transporte y la Logística en España' published data about freight transport between regions in Spain in 2017 on 'Memoria Anual 2018' [16] but it is difficult to translate these data to truck intensity by road. Instead, it is possible to estimate quantity of tonnes based in transported freight by truck and percentage of trucks in circulation with cargo. The January 2019 report of the 'Observatorio de costes del transporte de mercancías por carretera' [17] considered usual in Spain the semitrailer truck of 40-44 Tn that can transport a load of $25 \mathrm{Tn}$. But the truck does not always travel loading during a trip. The report cited consider a real cargo of $85 \%$ of its capacity. That is, as average, the trucks travel a $85 \%$ of time with cargo and a $15 \%$ of time without cargo. In addition, the truck can travel some trips without cargo. In fact, the truck travels to move cargo from origin to destination but does not always come back loaded. Consequently, in the worst-case scenario, the trucks run loaded for $50 \%$ of the trip while, in the best-case scenario, the trucks 
run loaded for $100 \%$ of the trip. That is, the percentage of loaded trucks in circulation can vary between a minimum of $50 \%$ and a maximum of $100 \%$. In fact, this percentage can vary, for example, between periods of economic crisis (more difficult to find cargo to come back) and periods of economic expansion. In this study we have used a percentage of $80 \%$ of loaded trucks in circulation. So, as average, the real load transportation that has been use is: $25 \times 0.85 \times 0.8=17 \mathrm{Tn} /$ truck. This coefficient allows to estimate load transport by tram of network and year.

\section{RESULTS}

Figures 3 and 4 show the results obtained in this study for passengers and freight transport. With respect to passenger transport, the corridors with the greatest potential to move passenger to railway mode are:

- Mediterranean corridor: Algeciras, Málaga, Múrcia, Alacant, València, Barcelona, France;

- A Coruña-Pontevedra;

- Madrid-Bilbao;

- Zaragoza-Bilbao.

Important corridors of passengers, like Madrid-Barcelona, Madrid-Sevilla or Madrid-València have less potential which is logical. Note you that these corridors, in 2017, had highspeed-rail services, and an important passenger traffic is by railway. Nevertheless, it does not exist rail network between Múrcia and Málaga, and it exists conventional train services between Múrcia-Alacant-València-Barcelona but no HSR services. So, for example, the

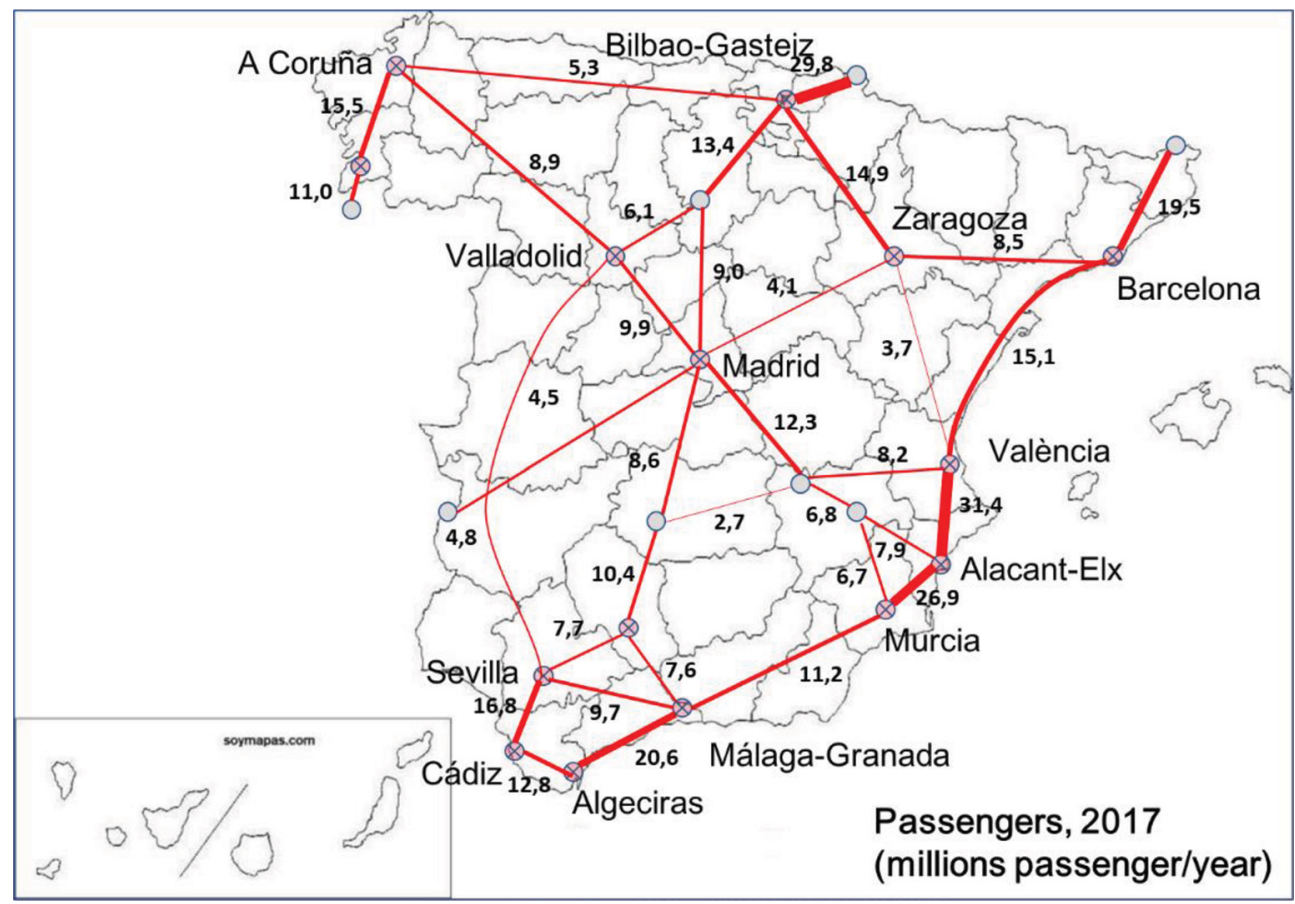

Figure 3: Main passenger corridors by road in Spain, 2017. 


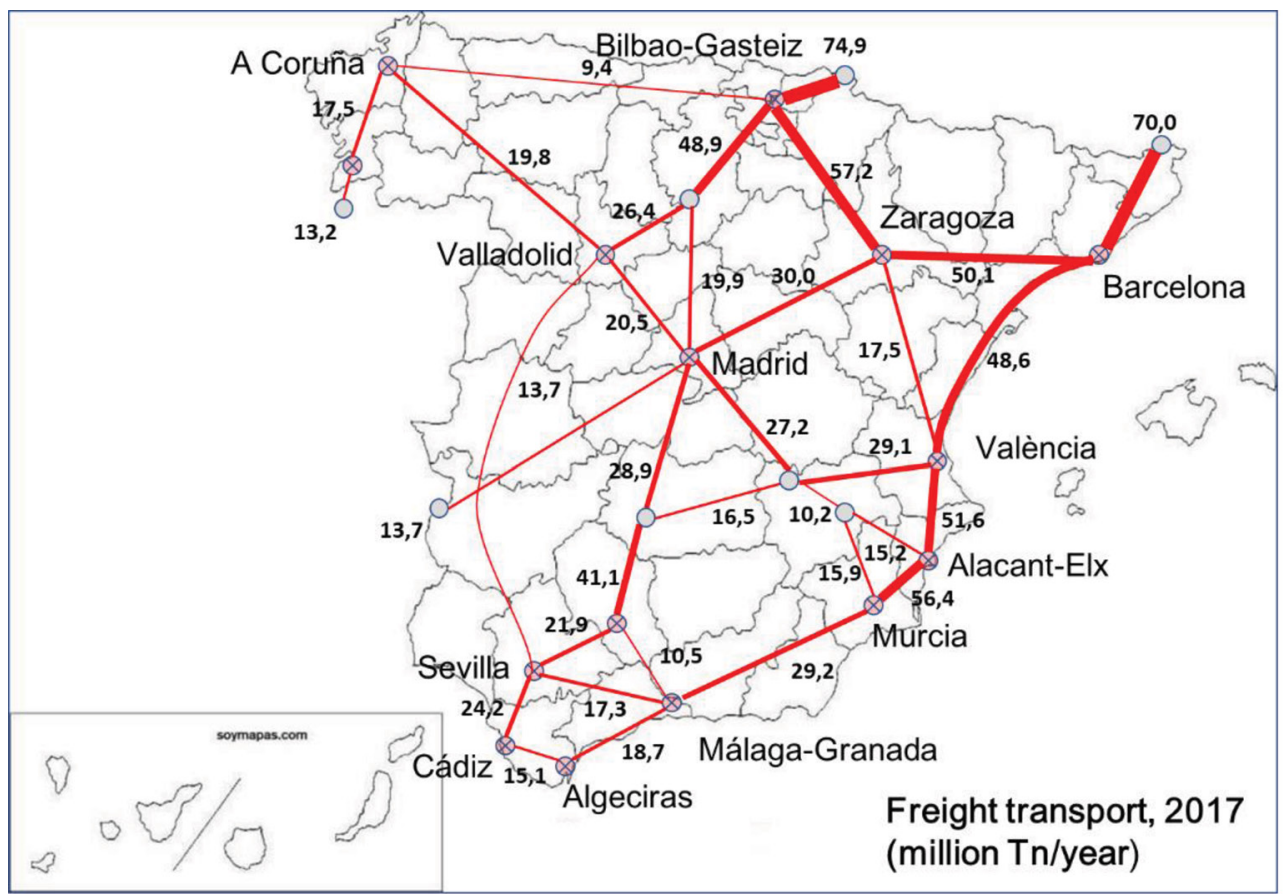

Figure 4: Main freight transport corridors by road in Spain, 2017.

passenger trip València-Madrid by HSR takes $1 \mathrm{~h} 40$ min while the passenger trip ValènciaBarcelona took more than $3 \mathrm{~h}$ in 2017 (now $2 \mathrm{~h}$ and $40 \mathrm{~min}$ ) by conventional train.

With respect to freight transport the situation is different. Remember you that freight transport by train in Spain is very low. So, the need to improve freight transport conditions are more general. In this case, the map of Fig. 4 really represents the absolute importance of each freight transport tram.

It is possible to do a classification of different situations according to the following list:

- International corridors to France from Bilbao and Barcelona: with the biggest quantity of freight transport that is logical because they are the door of road freight transport SpainEurope.

- Main corridors ( $\sim 50$ million Tn/year or more):

- Mediterranean corridor (part) Múrcia-Alacant-València-Barcelona-France: shows a very intense freight exchange between these urban areas.

- Ebro corridor Barcelona-Zaragoza-Bilbao: this corridor is located following the course of Ebro river; connect Zaragoza that is an important logistic centre, with industrial areas of Barcelona and Bilbao.

- Medium corridors (20-50 million Tn/year) that present an important quantity of transport but not so intense:

- Barcelona-Madrid,

- Bilbao-Madrid, 
- Madrid-Andalusia (Córdoba-Sevilla-Cádiz-Málaga),

- València-Madrid,

- Mediterranean corridor (part) Algeciras-Málaga-Múrcia.

- Low corridors (10-20 million Tn/year):

- Madrid-A Coruña (Galicia),

- International corridors with Portugal from A Coruña and Extremadura,

- West connection Sevilla (Andalusia)-Valladolid (Castile and Leon),

- València-Zaragoza,

- Bilbao-A Coruña.

So, this map presents a prioritized list of long-distance corridors to freight transport to move from road transport to train transport and, consequently, the prioritized list of train connections to improve. The map shows the importance of two main corridors: Mediterranean corridor (Algeciras-Málaga-Murcia-Alacant-València-Barcelona-French) and Ebro corridor (Barcelona-Saragossa-Bilbao-French).

Nevertheless, obviously, there are other criteria that can to justify improve train infrastructures. For example, Zaragoza and Algeciras (an important sea port) are two important logistic areas. This characteristic justifies improve radial freight train connection from these areas.

These analysis for passengers and freight based in corridors are important in order to maximize efficiency in ecological transition process moving freight transport from road to train. The analysis allows to identify the more important corridors to focus public investments on them as a way to maximize efficiency.

\section{CONCLUSIONS}

This kind of analysis allows to identify, by an argued bay, the priority corridors to move passenger and freight transport from road to railway according to the Green Deal European policy and coherent with Next Generation EU objectives. The analyses serve to prioritise inversion on railway infrastructures in order to minimize greenhouse gases emission.

The more important findings of this study are to show, in a justified way, the main road transport corridors for passengers and freight in Spain and, consequently, the priority connections to improve train services in order to move long-distance travels from road to train.

This study can be completed by similar maps of passengers and freight transport by other transport modes: train and air. In this way, it is possible to obtain a complete radiography of passengers and freight long-distance transport using corridors methodology and understand the more efficient way to will do the ecological transition in transport activity.

\section{ACKNOWLEDGEMENTS}

I want to recognize the consistent efforts carried out by municipalities of Almàssera, Bonrepòs i Mirambell, El Puig de Santa María, Foios, Massalfassar and Meliana of Valencian Community (Spain) which collaborated and financed the study with title 'ESTUDI DE TRAÇAT DE L'AVE PER L'AEROPORT DE MANISES I DEL CORREDOR MEDITERRANI EN L'ENTORN DE VALÈNCIA' that includes the analysis carried out that is the object of this article. 


\section{REFERENCES}

[1] Green Paper on the Urban Environment. Communication from the Commission to the Council and Parliament. COM (90) 218 final, 27 June 1990. Online, https://op.europa. eu/en/publication-detail/-/publication/fa89aeb7-e3a6-49a0-9a83-e9bd3a960cc7 (accessed 20 April 2021).

[2] Buchanan, C., Traffic in Towns, H.M. Stationery Office: London, 1963.

[3] Jacobs, J., The Death and Life of Great American Cities, Random House: New York, 1961.

[4] Libro Verde del Medio Ambiente Urbano. Tomo I; Ministerio de Medio Ambiente: Madrid, 2007. Online, http://habitat.aq.upm.es/lbl/guias/esp-2007-libroverde-medioambienteurbano.pdf (accessed 20 April 2021).

[5] Libro Verde de sostenibilidad urbana y local en la era de la información, Ministerio de Agricultura,Alimentación y MedioAmbiente:Madrid, 2012.Online, https://www.mitma. gob.es/recursos_mfom/pdf/9982755F-02CF-47D9-9571-0723387D66F7/130252/ Libro_Verde_Final_15012013_tcm7247905.pdf (accessed 20 April 2021).

[6] Statistical Pocketbook 2018; European Commission. Online, https://ec.europa.eu/ transport/facts-fundings/statistics/pocketbook-2018_en (accessed 20 June 2019).

[7] Los transportes y las infraestructuras. Informe anual 2015; Ministerio de Fomento. Online, https://www.fomento.gob.es/AZ.BBMF.Web/documentacion/pdf/M-642_2015.pdf (accessed 20 June 2019).

[8] De Ureña, J.M., (Ed), Territorial Implications of High Speed Rail, A Spanish Perspective, Routledge: London, 2017.

[9] Miralles i Garcia, J.L., Integration of high-speed train stations in cities: the case of Spain and Valencia City, International Journal of Transport Development and Integration, 1(2), pp. 677-694, 2017.

[10] Miralles i Garcia, J.L., High-speed rail and urban development in Spain from 1992 to 2016. 360. Revista de alta velocidad, 6, pp. 239-255, 2018.

[11] Miralles i Garcia, J.L., High-speed rail services in Spain and their relationship to population growth. WIT Transactions on the Built Environment, 182, pp. 1-13, 2019.

[12] Coronado, J.M.; de Ureña, J.M. \& Miralles, J.L., Short-and long-term population and Project implications of high-speed rail for served cities: analysis of all served Spanish cities and re-evaluation of Ciudad Real and Puertollano. European Planning Sudies, 27(3), pp. 434-460, 2019.

[13] Mapa de tráfico 2017. Ministerio de Transporte, Movilidad y Agenda Urbana. Online, https://www.mitma.es/carreteras/trafico-velocidades-y-accidentes-mapa-estimacion-yevolucion/mapas-de-trafico/2017 (accessed 20 April 2021).

[14] Recovery plan for Europe. European Commission. Online: https://ec.europa.eu/info/ strategy/recovery-plan-europe_en (accessed 20 April 2021).

[15] Anexo Metodológico 2019. Observatorio del Transporte y la Logística en España. Ministerio de Fomento: Madrid, 2020. Online, https://observatoriotransporte.mitma.es/ recursos_otle/anexo_metodologico_informe_anual_2019_1.pdf (accessed 30 April 2020).

[16] Memoria Anual 2018. Observatorio del Transporte y la Logística en España. Ministerio de Fomento: Madrid, 2019, pp 58. Online, https://observatoriotransporte.mitma.es/ recursos_otle/informe_otle_2018.pdf (accessed 20 April 2020).

[17] Observatorio de costes del transporte de mercancías por carretera. Enero 2019. Ministerio de Transporte, Movilidad y Agenda Urbana. Online, https://www.mitma.gob.es/recursos mfom/listado/recursos/observatorio_de_costes_enero_2019.pdf (accessed 30 April 2020). 